\section{Edema of the Bowel in Pigs}

This obscure condition, which was first described by Shanks' and Lamont ${ }^{2}$, has now become a major hazard to store-pigs in the whole of Ireland. It is now apparently causing serious concern in Great Britain. Repeated attempts at transmission by the staff at this laboratory have so far failed. A few months ago we came across a reference by Kurnick ${ }^{3}$ to a condition in the human characterized by œedema which was thought to be due to a protein deficiency. In July 1949, Dr. Mitchell, Dominion Pathologist, Canada, visited this laboratory, and he directed our attention to the work carried out by Gwatkin and his associates ${ }^{4}$ on the protein fraction in the diet of the pig.

We have carried out a series of serum protein estimations in the blood of the pig from litters in which deaths from gut œdema have been occurring. The estimations have been made by the biuret method using the Lovibond comparator.

Forty-four such blood samples have so far been examined, as well as a number of controls from litters with no history of gut œdema. Thirty-three control blood samples gave an average figure for serum protein of $6.64 \mathrm{gm}$. per cent. The highest figure was $8 \mathrm{gm}$. and the lowest was $5.5 \mathrm{gm}$. per cent. Forty-four samples of serum from 'in contact' and affected pigs ranged from $2.5 \mathrm{gm}$. per cent to $7.0 \mathrm{gm}$. per cent, with an average figure of $4.63 \mathrm{gm}$. per cent over all the samples.

It is emphasized that the vast majority of the latter group did not show any symptoms of the disease, even though the serum protein-level was much below the level of the control group. None of the sick pigs examined so far had a serum protein-level above $5 \mathrm{gm}$. per cent, though some of the 'in contact' apparently normal pigs in this group had also serum protein-levels of this low order. The preliminary work tends to show that, associated with this condition of gut œdema, there is a well-marked hypoproteinæmia.

The purpose of this note is to direct the attention of other research workers to this observation, which may prove significant in the etiology of this obscure condition.

The assistance given and the interest shown in this work by our technician, Mr. T. Cahil, is gratefully acknowledged.

$$
\begin{aligned}
& \text { D. LUKE } \\
& \text { W. A. M. Gordon }
\end{aligned}
$$

Veterinary Research Division, The Farm,

Stormont, Belfast.

Oct. 15.

${ }^{1}$ Shanks, P. L., Vet. Record, 50, 356 (1938).

- Lamont, H. G., Vet. Record, 50, 1377 (1938).

s Kurnick, N. B., Ann. Int. Med., 28, 782 (1948). Abstracted in Nut. Abs., 18, No. 2407 .

‘ Gwatkin, R., Moynihan, I. W., and Bankier, J. C., Can. J. Comp. Med., $6,5$.

\section{Geographical Distribution of the Body- Weight/Body-Surface Ratio}

Is the course of biometrical work concerning twenty different human samples-the individual figures partly obtained by myself and partly taken from other sources- I have found the following values for the body-weight/body-surface ratio (kgm./m.2) :

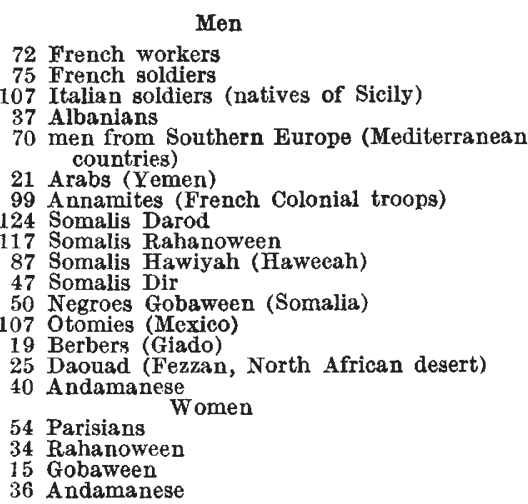

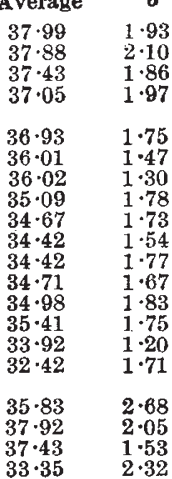

When we compare geographically distant groups, the differences are statistically significant. For example, if we compare the lowest European average $(36.93)$ and the highest non-European average $(36 \cdot 02)$, we find that the ratio of difference to standard error of difference is 3.6 ; the same ratio is 5.0 if we compare French workers with Arabs, and 10.3 if we compare the same workers with Darod Somalis.

There is obviously a decline of the value of the ratio as we proceed from temperate to tropical regions. Of course, ratios do not follow exactly either latitudes or isotherms-such would be indeed surprising-but the general tendency is clear. Perhaps, even in Europe there is some decrease from north to south. The last of the 'Europoid' samples (Yemenite Arabs) is apparently outside the European range, the lower limit of which, for the adult male, seems to be approximately $37 \cdot 00$. The Arabs have practically the same ratio as the Annamites (natives of Tonkin, northern Indo-China, a country with a relatively fair tropical climate). The decrease is more evident if we compare European values with those of other samples from desert or tropical surroundings.

Now, the ratio weight/surface plays a part in the regulation of body-heat. In a hot climate a relative deficiency of body-mass-or relative excess of bodysurface is an advantage. Possibly climatic agencies operated selectively with a convergent result; but, if so, it would be a peculiar lkind of convergency, with radically divergent anatomical implications, as the same biologically important ratio is attained by the extreme dolichomorphs (Somalis) and the extreme brachymorphs (Otomis).

If this be true, we must admit at the same time the interference of an independent sexual factor, for the position is not the same with women. Unfortunately, the latter are represented only by four samples (I lost during the War the data concerning Otomi women I measured in 1936). Nevertheless, there appears to be a racial as well as a sexual difference : the average ratio for French women is definitely lower than the ratio for any European male sample ; the ratio for 'tropical' women is definitely higher than the ratio for men of the same stock. It must be remembered that, in women, heat regulation does not work in exactly the same way as in men.

A full account of these findinge, together with a detailed anthropometrical body-build analysis, of eleven kinds of males and three kinds of females, will be published in l'Anthropologie.

\section{Euginne ScHreIder}

\section{Laboratoire d'Anthropologie Physique,}

I rue René-Panhard, Paris, XIII.

$$
\text { Oct. } 3 .
$$

